\title{
Aplikasi Forecasting Stok Barang Menggunakan Metode Weighted Moving Average (WMA) pada Metrojaya Komputer
}

\author{
Imam Solikin ${ }^{1 *}$, Septa Hardini ${ }^{2}$ \\ ${ }^{1}$ Program Studi Manajemen Informatika, Fakultas Vokasi, Universitas Bina Darma, Palembang \\ ${ }^{2}$ Program Studi Teknik Industri, Fakultas Teknik, Universitas Bina Darma, Palembang \\ ${ }^{1,2} \mathrm{Jln}$. Jendral A. Yani No.03, Kota Palembang, Indonesia \\ email: 1 imamsolikin@binadarma.com, ${ }^{2}$ septa.hardini@binadarma.ac.id
}

\begin{abstract}
Metrojaya Komputer is a business engaged in buying and selling, the purchasing process often has difficulty in determining how much stock of goods must be purchased for the future period, because it has not used forecasting methods. Forecasting is a forecasting that requires the retrieval of historical data to be processed in order to produce a decision on what predictions are needed for the next period. The purpose of this research is to simplify and accelerate forecasting using the weighted moving average (WMA) approach through the development of information technology based systems. The data needed in forecasting is the previous period data, whether the previous month's data or the previous year, then processed using forecasting equation. Forecasting can be processed based on data from the previous three periods or based on a certain period to produce the required stock of goods. The system development method used is the waterfall method which consists of several stages of communication, planning, modeling, construction, and deployment. This study produces a forecasting information system with a weighted moving average (WMA) approach that can be processed using an information technology based system so that it makes it easier and faster in making decisions regarding the stock of goods needed in sales.
\end{abstract}

Keywords: Forecasting, WMA, Waterfall

Abstrak - Metrojaya Komputer merupakan suatu usaha yang bergerak dibidang jual beli, proses pembelian sering mengalami kesulitan dalam menentukan berapa jumlah stok barang yang harus dibeli untuk periode kedepannya, karena belum menggunakan metode forecasting. Forecasting merupakan peramalan yang memerlukan pengambilan data historis untuk diproses supaya menghasilkan keputusan berapa prediksi stok barang yang diperlukan untuk periode selanjutnya. Tujuan dilakukan penelitian ini untuk mempermudah dan mempercepat melakukan forecasting dengan metode pendekatan weighted moving average (WMA) melalui pengembangan sistem berbasis teknologi informasi. Adapun data yang diperlukan dalam forecasting adalah data periode sebelumnya baik itu data perbulan sebelumnya atau pertahun sebelumnya kemudian diproses menggunakan persamaan forecasting. Forecasting dapat diproses berdasarkan data tiga periode sebelumnya atau berdasakan periode tertentu untuk menghasilkan kebutuhan stok barang yang diperlukan dalam penjualan. Metode pengembangan sistem yang digunakan adalah metode waterfal yang terdiri dari beberapa tahapan communication, planning, modeling, construction, dan deployment. Penelitian ini

*) penulis korespondensi: Imam Solikin

Email: imamsolikin@binadarma.ac.id menghasilkan sistem informasi forecasting dengan metode pendekatan weighted moving average (WMA) yang dapat diproses menggunakan sistem berbasis teknologi informasi sehingga mempermudah dan mempercepat dalam pengambilan keputusan prediksi stok barang yang dibutuhkan dalam penjualan.

Kata Kunci-Forecasting, WMA, Waterfall

\section{PENDAHULUAN}

Kemajuan teknologi informasi (IT) sekarang ini mengalamin perkembangan sangat pesat. Kemajuan teknologi informasi tersebut dapat dimanfaatkan di dunia bisnis atau perdagangan dalam mendukung proses peramalan (forecasting) atau prediksi stok barang yang akan dibutuhankan. "Forecasting merupakan seni dan ilmu yang memprediksi kejadian di masa depan dengan melibatkan pengambilan data historis dan memproyeksikannya kemasa mendatang dengan model pendekatan sistematis" [1].

Metrojaya Komputer merupakan tempat penjualan berbagai macam laptop, printer, proyektor, aksesoris elektronik dan berbagai macam lainnya. Kegiatan yang ada pada Metrojaya Komputer antara lain transaksi pembelian stok barang dan transaksi penjualan. Pada transaksi pembelian stok barang Metrojaya Komputer sering mangalami kesulitan dalam menentukan berapa banyak stok yang harus dibeli untuk periode kedepannya, karena belum menggunakan metode forecasting stok barang yang akan dibeli. Hal tersebut mengakibatkan sering terjadinya kekurang stok barang atau bahkan ada banyak stok barang yang tersisa. Sistem seperti ini membuat kegiatan pada Metrojaya Komputer menjadi kurang efektif dalam proses penjualan dan pembelian.

Forecasting (peramalan) merupakan cara untuk memprekdiksikan pengaruh kondisi dan situasi yang berlaku terhadap perkembangan pada masa yang akan datang [2]. Forecasting juga merupakan suatu prediksi dengan menggunakan teknik-teknik tertentu [3]. Penjelasan lain tentang forecasting adalah pernyataan mengenai nilai untuk periode selanjutnya dari variabel, prediksi yang lebih baik dapat dijadikan keputusan dengan menggunakan banyak informasi [4].

Metode pendekatan forecasting yang diterapkan dalam penelitian ini yaitu metode weighted moving average (WMA). Metode WMA disebut juga metode rata-rata bergerak, untuk menghitung peramalan bobot terbesar diberikan pada nilai 
terbaru dari deret nilai berkala [5]. Penerapan forecasting dengan metode WMA digunakan untuk mengontrol pembelian stok barang. Penentuan forecasting pada penelitian ini selain dengan metode WMA juga dibahas dengan metode metode single moving avarage (SMA). Metode SMA merupakan metode yang digunakan untuk peramalan dengan cara mengambil sekelompok nilai pengamatan untuk menentukan nilai rata-rata, nilai tersebut sebagai peramalan yang digunakan pada periode yang akan datang [6]. Keunggulan dari penggunaan metode WMA yaitu lebih responsif dalam memprediksi perubahan trend dibadinggkan metode lain [7]. Pada metode WMA dilakukan pembobotan penilaian, data terakhir mempunyai bobot yang lebih besar dibadingkan data sebelumnya, hal ini dilakukan karena penggerakan data terakhir akan lebih representatif dalam memprediksi stok barang kedepannya. Lain hal pada metode SMA hanya menghitung nilai rata-rata dari semua data. Tujuan dari penggunaan metode forecasting adalah untuk mendapatkan prediksi stok barang yang akan dibeli yang bisa meminimumkan kesalahan dalam pembelian stok barang.

\section{PENELITIAN YANG TERKAIT}

Penelitian sebelumnya yang berkaitan dengan penelitian ini antara lain, "prediksi persediaan barang menggunakan metode weighted moving average dan double exponential smoothing" [8]. "Penerapan metode exponentially weighted moving average dan metode semi varioans dalam perhitungan risiko portofolio saham PT Pindad Persero" [9]. "Sistem forecasting persediaan barang dengan weighted moving average di Toko The Kids 24" [10]. Pada tiga penelitian tersebut bertujuan untuk memperdiksikan persediaan stok barang untuk periode mendatang dengan menggunakan metode forecasting menggunakan bobot nilai setiap datanya.

"Sistem informasi peramalan pembelian stok barang menggunakan metode single moving average" [11]. "Penerapan metode moving average dan exponential smoothing pada peramalan produk industri Garment" [12]. "Analisa penggunaan metode peramalan pada perusahaan retail sistem tradisional market" [13]. Pada tiga penelitian ini, peramalan dilakukan dengan mencari nilai rata-rata dari semua data yang digunakan untuk peramalan.

Keterkaitan enam (6) artikel penelitian tersebut dengan penelitian ini adalah isi dari pembahasan yang mengarah forecasting walaupun metode yang digunakan berbeda adapun tujuan umum dari peramalan untuk meminimumkan kesalahan dalam pembelian stok barang. Dalam penelitian yang dijadikan referensi juga menjelaskan gambaran keuntungan bahkan juga menjelaskan kelemahannya.

\section{METODE PENELITIAN}

Metode penelitian yaitu cara ilmiah dalam mengumpulkan data untuk tujuan dan kegunaan tertentu [14], definisi lain dari metode penelitian yaitu anggapan dasar tentang suatu hal yang dijadikan landasan berfikir dan bertindak dalam melaksanakan penelitian [15].

\section{A. Teknik pengumpulan data}

Teknik pengumpulan data merupakan langkah yang paling strategis dalam penelitian, karena tujuan utama dari penelitian adalah mendapatkan data [14].
- Teknik Interview berupa pengumpulan data yang banyak digunakan dalam penelitian kualitatif [16]. Interview dilakukan kepada pihak metrojaya komputer mengenai bagaimana cara melakukan pembelian stok barang, penjualan stok barang, dan permasalahan yang dihadapi dalam menentukan pembelian persediaan stok barang.

- Teknik pengamatan/observasi yang dilakukan oleh observer yang terlibat langsung dalam data tentang aktifitas pegawai dan pemilik Metrojaya Komputer dalam proses pembelian stok barang dan penjualan stok barang [17]. Observasi dikakukan terhadap berapa jumlah stok barang yang masih ada pada Metrojaya Komputer pada akhir periode.

- Teknik dokumen merupakan barang atau dalam bentuk tertulis [18]. Dokumen yang didapat dari Metrojaya Komputer berupa data penjualan barang setiap periode, data pembelian stok barang setiap periode, serta data persediaan barang yang masih ada pada Metrojaya Komputer.

\section{B. Kerangka berfikir}

Model pengembangan sistem yang diterapkan pada penelitian ini yaitu model waterfall yang merupakan model klasik yang bersifat sistematis dalam membangun software [19]. Dalam membangun sistem, langkah-langkah yang diperlukan pertama adalah pengumpulan data dari Metrojaya Komputer, kemudian membangun sistem forecasting laptop dengan menggunakan metode weighted moving average, dilanjutkan dengan pengujian, langkah terakhir yaitu implementasi sistem forecasting.

Kerangkan berfikir sistem forecasting stok barang pada Metrojaya Komputer menggunakan metode weighted moving average dapat dilihat pada gbr 1 .

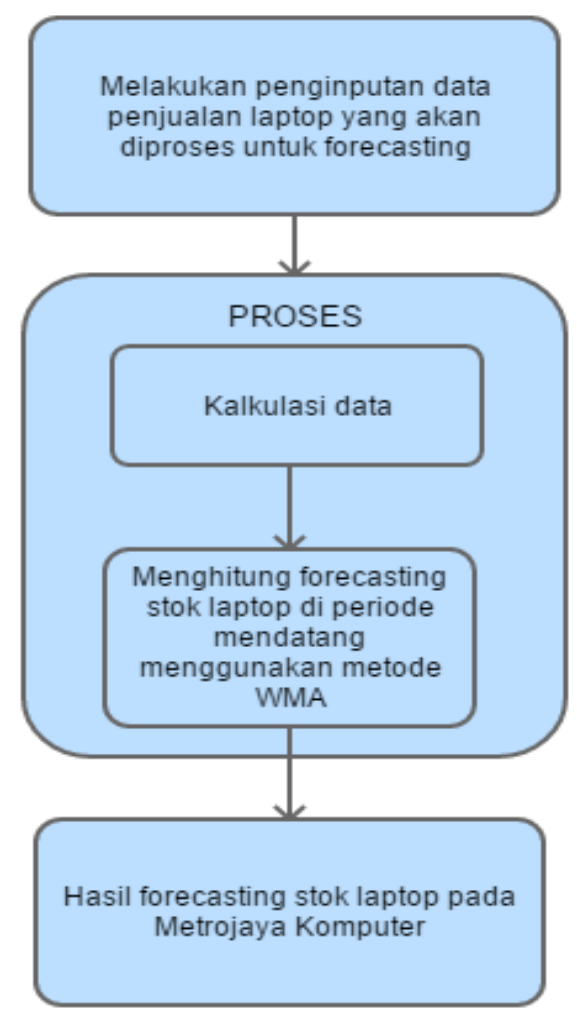

Gbr. 1 Kerangka berfikir sistem forecasting pada Metrojaya Komputer [20] 


\section{Pendekatan forecasting kuantitatif}

Pada pendekatan ini, metode yang digunakan berhubungan dengan ilmu matematika dan ilmu statistik [18]. Metode kuantitatif terdapat dua (2) jenis antara lain kelompok analisa sebab akibat (causal method) dan analisa deret berkala (time series). Adapun salah satu cara untuk menghitung deret berkala adalah dengan menggunakan metode pendekatan weighted moving average.

\section{Single moving average (SMA)}

Single moving average (SMA) merupakan metode forecasting yang diproses dengan mengambil sekelompok nilai pengamatan untuk mencari nilai rata-rata sebagai nilai forecasting untuk periode selanjutnya [6]. Metode SMA menggunakan sejumlah data actual permintaan yang baru untuk memperoleh nilai forecasting untuk permintaan periode selanjutnya [21]. Metode SMA ini bisa efektif diterapkan jika dapat mengasumsikan bahwa permintaan pasar terhadap produk akan tetap selalu stabil [22]. Adapun persamaan untuk menghitung forecasting menggunakan metode SMA dapat dilihat pada rumus $1,[23]$, [21].

$S_{t}=\frac{x_{t}+x_{t-1}+\cdots+x_{t-1+1}}{n}$

\section{Keterangan}

$\mathrm{S}_{\mathrm{t}} \quad=$ forecast untuk periode ke $\mathrm{t}+1$,

$\mathrm{X}_{\mathrm{t}} \quad=$ data pada periode $\mathrm{t}$,

$\mathrm{n} \quad=$ jangka waktu SMA

\section{E. Weighted moving average (WMA)}

Metode weighted moving average (WMA) atau metode rata-rata bergerak tertimbang yang terlebih dahulu menejemen data menetapkan bobot (weighted factor) dari data yang ada. Penetapan bobot dimaksud besifat subjektif, tergantung pada pengalaman dan ketentuan analis data [24]. Perhitungan metode weighted moving average setiap historis mempunyai bobot yang berbeda, bobot terbesar diberikan pada data historis yang paling akhir dalam setiap periode dibandingkan dengan data historis yang sebelumnya sebab data yang paling baru merupakan data yang paling relevan dalam forecasting [25]. Adapun persamaan untuk menghitung forecasting menggunakan metode WMA dapat dilihat pada rumus 2 dan rumus $3,[10]$,

$\mathrm{F}_{1}=\sum_{\mathrm{i}=1}^{\mathrm{n}} \mathrm{w}_{\mathrm{i}} \mathrm{A}_{\mathrm{t}}$

$\mathrm{F}_{1}=\mathrm{w}_{1} \mathrm{~A}_{\mathrm{t}-1}+\mathrm{w}_{2} \mathrm{~A}_{\mathrm{t}-2}+\mathrm{w}_{3} \mathrm{~A}_{\mathrm{t}-3}+\cdots+\mathrm{w}_{\mathrm{n}} \mathrm{A}_{\mathrm{t}}-\mathrm{n}$

\section{Keterangan}

$\mathrm{F}_{1} \quad=$ forecasting volum permintaan periode akan datang,

Wt $\quad$ Bobot (probabilitas) keberulangan kegiatan ke-1 di masa datang, pembobotan atau $\mathrm{W}$ ditentukan sedemikian rupa dengan jumlah keseluruhan sama dengan satu (Sundari et al., 2015),

At-1 = Volum permintaan pada waktu sebelumnya,

At-1 At-2 At-n = Volum permintaan dua (2), tiga (3), atau n periode sebelumnya.
Misal untuk rata-rata bergerak 3 bulan dengan bobot sebagai berikut : $0,5,0,3$, dan 0,2 dan misal untuk rata-rata bergerak 4 bulan dengan bobot sebagai berikut : 0,4, 0,3, 0,2, dan 0,1 . Adapun alur sistem forecasting menggunakan metode WMA dapat dilihat pada gbr 2 [26].

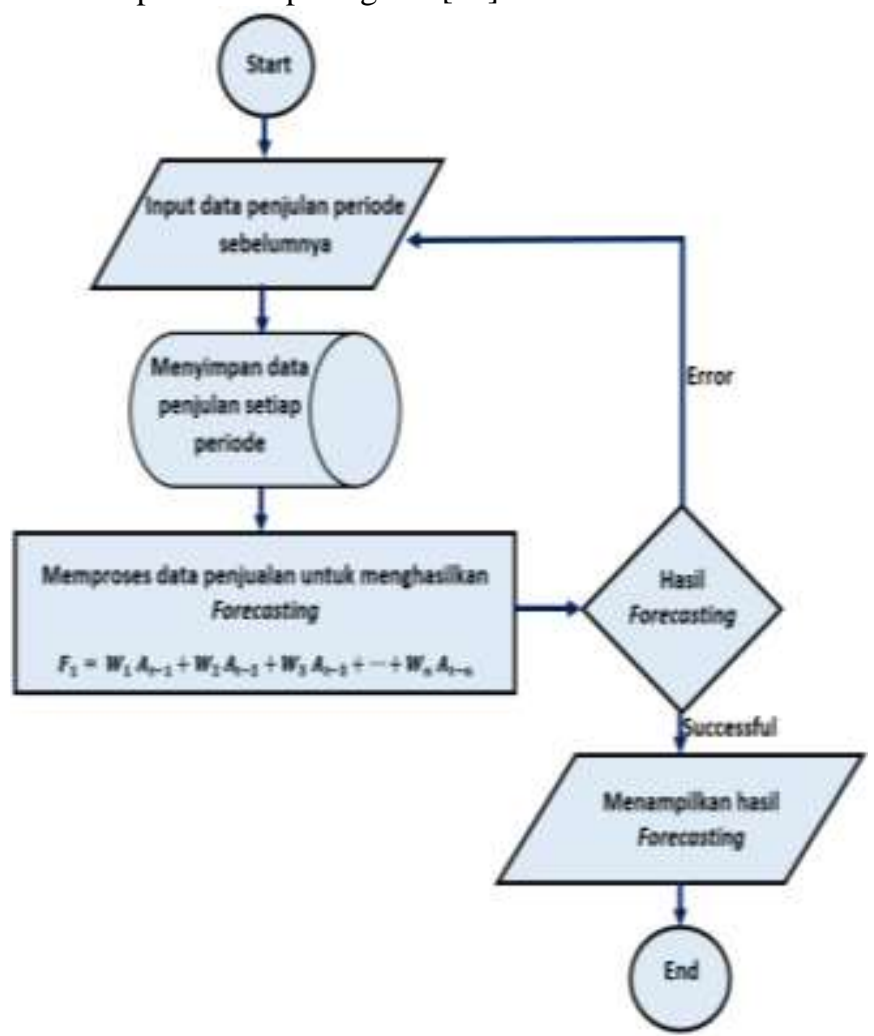

Gbr. 2 Flowchart forecasting [26]

\section{HASIL DAN PEMBAHASAN}

Setelah melakukan analisis dan desain sistem maka dilanjutkan dengan pengkodingan, sehingga dihasilkan sistem forecasting stok barang pada Metrojaya Komputer. Sistem forecasting digunakan untuk mendukung proses prediksi pembelian stok barang untuk periode selanjutnya, dengan tujuan untuk meminimalisir kesalahan dalam pembelian stok barang.

1) Login

Interface login merupakan interface yang muncul pada awal ketika sistem forecasting diakses, interface ini digunakan oleh admin untuk masuk ke sistem forecasting dengan menggunakan user id dan password yang sudah dimiliki. interface login sistem forecasting dapat dilihat pada gbr 3 .

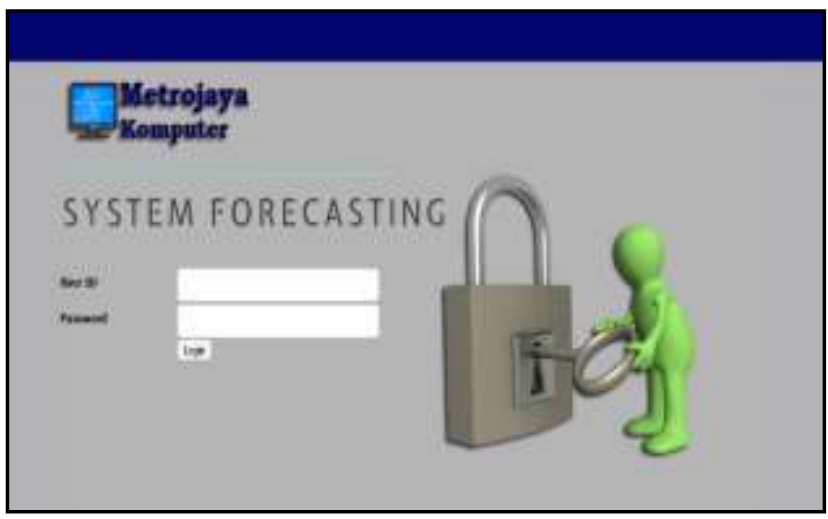

Gbr. 3 Login admin 


\section{2) Data penjualan perperiode}

Interface ini digunakan untuk menginputkan data jumlah penjualan setiap periodenya yang nantinya akan diproses untuk menghasilkan forecasting menggunakan metode weighted moving average. Interface ini dapat dilihat pada gbr 4 .

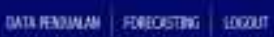

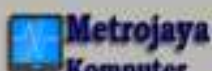

\section{Input Laporan Penjualan Per-periode}

Nat

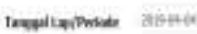

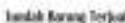

Gbr. 4 Data penjualan perperiode

3) Forecasting menggunakan metode weighted moving average (WMA) pertriwulan

Forecasting ini merupakan memproses data berdasarkan data tiga bulan sebelumnya untuk menghasilkan forecasting periode selanjutnya menggunakan metode weighted moving average, adapun pembobotan untuk perhitungan tiga bulan (April, Mei, dan Juni) adalah 0,2 +0,3 +0,5=1. Adapun salah satu hasil perhitungan yang dilakukan pertriwulan menggunakan metode WMA dapat dilihat pada tabel 1.

Tabel I

FORECASTING MENGGUNAKAN METODE WMA PERTRIWULAN

\begin{tabular}{|c|c|c|c|c|c|}
\hline \multirow{2}{*}{$\begin{array}{c}\text { Merk } \\
\text { Laptop }\end{array}$} & \multicolumn{2}{|c|}{ Bulan/Pembobota } & \multicolumn{2}{|c|}{$\begin{array}{c}\text { Hasil } \\
\text { Forecasting } \\
\text { Untuk Bulan Juli }\end{array}$} \\
\cline { 2 - 6 } & $\begin{array}{c}\text { April } \\
\text { /0,5 }\end{array}$ & $\begin{array}{c}\text { Mei } \\
\mathbf{/ 0 , 3}\end{array}$ & $\begin{array}{c}\text { Jun } \\
\mathbf{/ 0 , 2}\end{array}$ & $\boldsymbol{F}_{\mathbf{1}}$ & Penjualan \\
\hline $\begin{array}{c}\text { Acer } \\
\text { Celeron } \\
11,6 \text { inchi }\end{array}$ & 23 & 13 & 18 & 17,5 & 16 \\
\hline $\begin{array}{c}\text { Acer i3 } \\
14 \text { inchi }\end{array}$ & 21 & 9 & 15 & 14,4 & 14 \\
\hline $\begin{array}{c}\text { Acer i5 } \\
14 \text { inchi }\end{array}$ & 15 & 12 & 17 & 15,1 & 13 \\
\hline $\begin{array}{c}\text { Acer i7 } \\
14 \text { inchi }\end{array}$ & 17 & 15 & 14 & 14,9 & 14 \\
\hline $\begin{array}{c}\text { Lenovo } \\
\text { Celeron } \\
10 \text { inchi }\end{array}$ & 19 & 11 & 15 & 14,6 & 12 \\
\hline $\begin{array}{c}\text { Lenovo } \\
\text { Celeron } \\
14 \text { inchi }\end{array}$ & 13 & 16 & 14 & 14,4 & 10 \\
\hline $\begin{array}{c}\text { Lenovo i3 } \\
14 \text { inchi }\end{array}$ & 10 & 14 & 15 & 13,7 & 12 \\
\hline $\begin{array}{c}\text { Lenovo i5 } \\
14 \text { inchi }\end{array}$ & 15 & 13 & 11 & 12,4 & 10 \\
\hline
\end{tabular}

Salah satu perhitungan forecasting menggunakan metode WMA untuk periode juli berdasarkan datang tiga bulan sebelumnya, jenis barang yang dihitung adalah laptop acer celeron 11,6 inchi

$$
\begin{aligned}
\mathrm{F} 1 & =(23 * 0,2)+(13 * 0,3)+(18 * 0,5) \\
& =4,6+3,9+9 \\
& =17,5
\end{aligned}
$$

Hasil implementasi dalam sistem untuk forecasting menggunakan metode WMA berdasarkan data 3 (tiga) bulan sebelumnya, proses ini dapat dilihat pada gbr 5 .

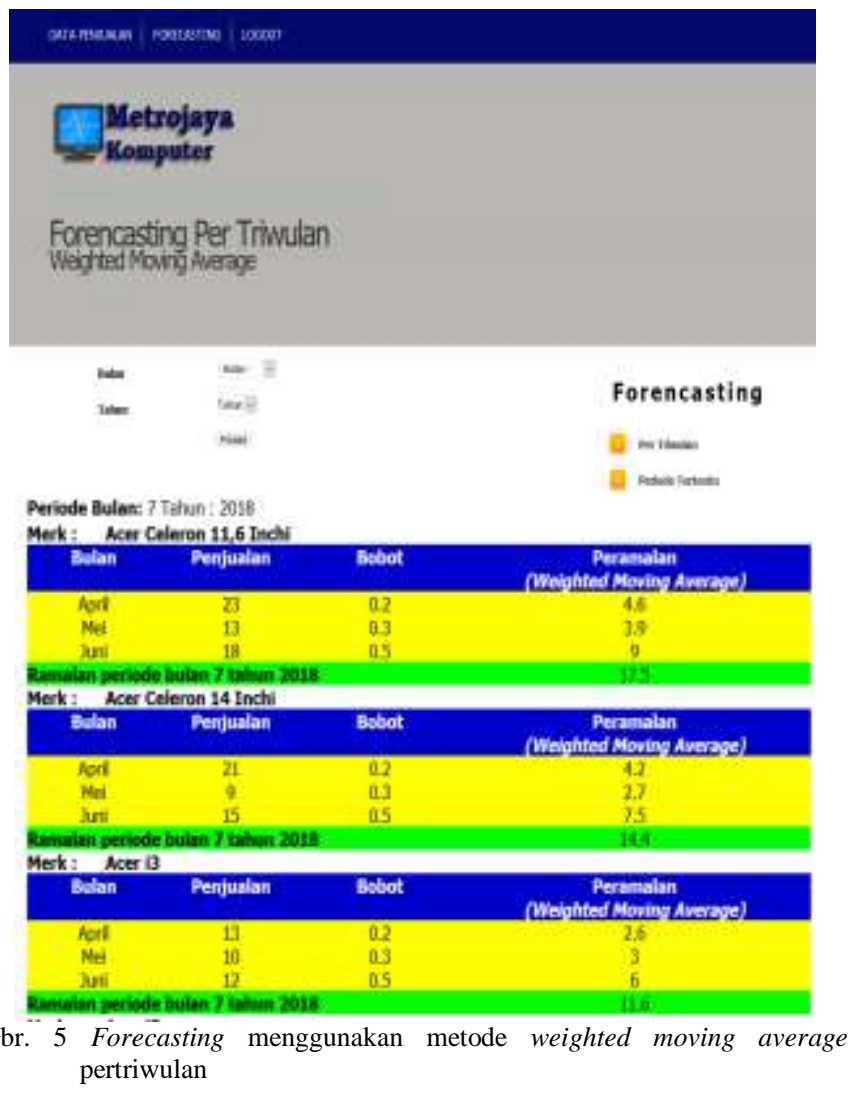

TABEL III

FORECASTING MENGGUNAKAN METODE SMA PERTRIWULAN

\begin{tabular}{|c|c|c|c|c|c|}
\hline \multirow{2}{*}{$\begin{array}{c}\text { Merk } \\
\text { Laptop }\end{array}$} & \multicolumn{3}{|c|}{ Bulan } & \multicolumn{2}{|c|}{$\begin{array}{c}\text { Hasil } \\
\text { Forecasting } \\
\text { Untuk Bulan } \\
\text { Juli }\end{array}$} \\
\cline { 2 - 6 } & April & Mei & Juni & $S_{t}$ & $\begin{array}{c}\text { Penjuala } \\
\text { n }\end{array}$ \\
\hline $\begin{array}{c}\text { Acer } \\
\text { Celeron } \\
11,6 \text { inchi }\end{array}$ & 23 & 13 & 18 & 18 & 16 \\
\hline $\begin{array}{c}\text { Acer i3 } \\
14 \text { inchi }\end{array}$ & 21 & 9 & 15 & 15 & 14 \\
\hline $\begin{array}{c}\text { Acer i5 } \\
14 \text { inchi }\end{array}$ & 15 & 12 & 17 & 14,7 & 13 \\
\hline $\begin{array}{c}\text { Acer i7 } \\
14 \text { inchi }\end{array}$ & 17 & 15 & 14 & 15,4 & 14 \\
\hline $\begin{array}{c}\text { Lenovo } \\
\text { Celeron } \\
10 \text { inchi }\end{array}$ & 19 & 11 & 15 & 15 & 12 \\
\hline
\end{tabular}




\begin{tabular}{|c|c|c|c|c|c|}
\hline $\begin{array}{c}\text { Lenovo } \\
\text { Celeron } \\
14 \text { inchi }\end{array}$ & 13 & 16 & 14 & 14,3 & 10 \\
\hline $\begin{array}{c}\text { Lenovo i3 } \\
14 \text { inchi }\end{array}$ & 10 & 14 & 15 & 13 & 12 \\
\hline $\begin{array}{c}\text { Lenovo i5 } \\
14 \text { inchi }\end{array}$ & 15 & 13 & 11 & 13 & 10 \\
\hline
\end{tabular}

Salah satu perhitungan forecasting menggunakan metode SMA untuk periode juli berdasarkan datang tiga bulan sebelumnya.

$$
\begin{aligned}
\mathrm{Ft} & =(23+13+18) / 3 \\
& =54 / 3 \\
& =18
\end{aligned}
$$

\begin{tabular}{|c|c|c|c|c|c|c|c|c|}
\hline No & \multicolumn{3}{|c|}{ Bulan/Pembobotan } & \multirow{2}{*}{$\begin{array}{c}\text { Penjualan } \\
\text { Aktual }\end{array}$} & \multirow{2}{*}{$\begin{array}{c}F_{1} \\
(0,5 / 0,3 / 0,2)\end{array}$} & \multirow{2}{*}{$S_{t}$} & \multirow{2}{*}{$\begin{array}{l}\text { Error WMA } \\
\qquad\left(F_{1}\right)\end{array}$} & \multirow{2}{*}{$\begin{array}{c}\text { Error SMA } \\
\qquad\left(S_{t}\right)\end{array}$} \\
\hline 1 & April & Mei & Juni & & & & & \\
\hline 2 & 23 & 13 & 18 & 16 & 17,5 & 18 & -1 & -2 \\
\hline 3 & 21 & 9 & 15 & 14 & 14,4 & 15 & 0 & -1 \\
\hline 4 & 15 & 12 & 17 & 13 & 15,1 & 14,7 & -2 & -1 \\
\hline 5 & 17 & 15 & 14 & 14 & 14,9 & 15,4 & 0 & -1 \\
\hline 6 & 19 & 11 & 15 & 12 & 14,6 & 15 & -2 & -3 \\
\hline 7 & 13 & 16 & 14 & 10 & 14,4 & 14,3 & -4 & -4 \\
\hline 8 & 10 & 14 & 15 & 12 & 13,7 & 13 & -1 & -1 \\
\hline 9 & 15 & 13 & 11 & 10 & 12,4 & 13 & -2 & -3 \\
\hline
\end{tabular}

TABEL III

MENGHITUNG ERROR MENGGUNAKAN METODE WMA $\left(\mathrm{F}_{1}\right)$ DAN SMA $\left(\mathrm{S}_{\mathrm{t}}\right)$ PERTRIWULAN

4) Forecasting menggunakan metode weighted moving average Berdasarkan periode tertentu

Adapun salah satu hasil perhitungan yang dilakukan berdasarkan periode tertentu menggunakan metode WMA bisa dilihat pada tabel 2.

TABEL IV

\begin{tabular}{|c|c|c|c|c|}
\hline \multicolumn{5}{|c|}{ Jenis barang : Acer Celeron 11,6 inchi } \\
\hline Bulan & Tahun & $\begin{array}{c}\text { Hasil } \\
\text { Penjualan } \\
\text { (W) }\end{array}$ & $\begin{array}{c}\text { Bobot } \\
\text { (A) }\end{array}$ & $F_{1}$ \\
\hline Januari & 2018 & 25 & 0,15 & 3,75 \\
\hline Februari & 2018 & 27 & 0,15 & 4,05 \\
\hline Maret & 2018 & 30 & 0,15 & 4,5 \\
\hline April & 2018 & 23 & 0,15 & 3,45 \\
\hline Mei & 2018 & 13 & 0,15 & 1,95 \\
\hline Juni & 2018 & 18 & 0,25 & 4,5 \\
\hline \multicolumn{4}{|c|}{$\begin{array}{l}\text { Forecasting menggunakan metode WMA } \\
\text { bulan Juli }\end{array}$} & 22,2 \\
\hline
\end{tabular}

FORECASTING MENGGUNAKAN METODE WMA DERDASARKAN PERIODE TERTENTU

Salah satu perhitungan forecasting untuk periode juli berdasarkan datang enam bulan sebelumnya menggunakan metode WMA, jenis barang yang dihitung adalah laptop acer celeron 11,6 inchi.

$$
\begin{aligned}
& \mathrm{F} 1=(25 * 0,15)+(27 * 0,15)+(30 * 0,15)+(23 * 0,15) \\
& +(13 * 0,15)+(18 * 0,25) \\
& \quad=3,75+4,05+4,5+3,45+1,95+4,5 \\
& =22,2
\end{aligned}
$$

Pada forecasting tabel $\mathrm{V}$, data yang diproses dapat ditentukan sendiri berapapun jumlah periode sebelumnya yang ingin dimasukan dan diproses untuk menghasilkan forecasting periode selanjutnya dengan menggunakan metode weighted moving average. Hasil implementasi dalam sistem untuk forecasting menggunakan metode WMA berdasarkan data 6 (enam) bulan sebelumnya, dapat dilihat pada gbr 6 .
TABEL V

FORECASTING MENGGUNAKAN METODE SMA DERDASARKAN PERIODE TERTENTU

\begin{tabular}{|l|c|c|}
\hline \multicolumn{2}{|c|}{ Jenis barang : Acer Celeron 11,6 inchi } \\
\hline Bulan & Tahun & Hasil Penjualan (W) \\
\hline Januari & 2018 & 25 \\
\hline Februari & 2018 & 27 \\
\hline Maret & 2018 & 30 \\
\hline April & 2018 & 23 \\
\hline Mei & 2018 & 13 \\
\hline Juni & 2018 & 18 \\
\hline \multicolumn{2}{|c|}{ Forecasting menggunakan } & 22.6 \\
metode SMA $\left(\mathrm{S}_{\mathrm{t}}\right)$ bulan Juli & \\
\hline
\end{tabular}

Salah satu perhitungan forecasting menggunakan metode SMA untuk periode juli berdasarkan datang 6 (enam) bulan sebelumnya.

$$
\begin{aligned}
\mathrm{Ft} & =(25+27+30+23+13+18) / 6 \\
& =136 / 6 \\
& =22.67
\end{aligned}
$$




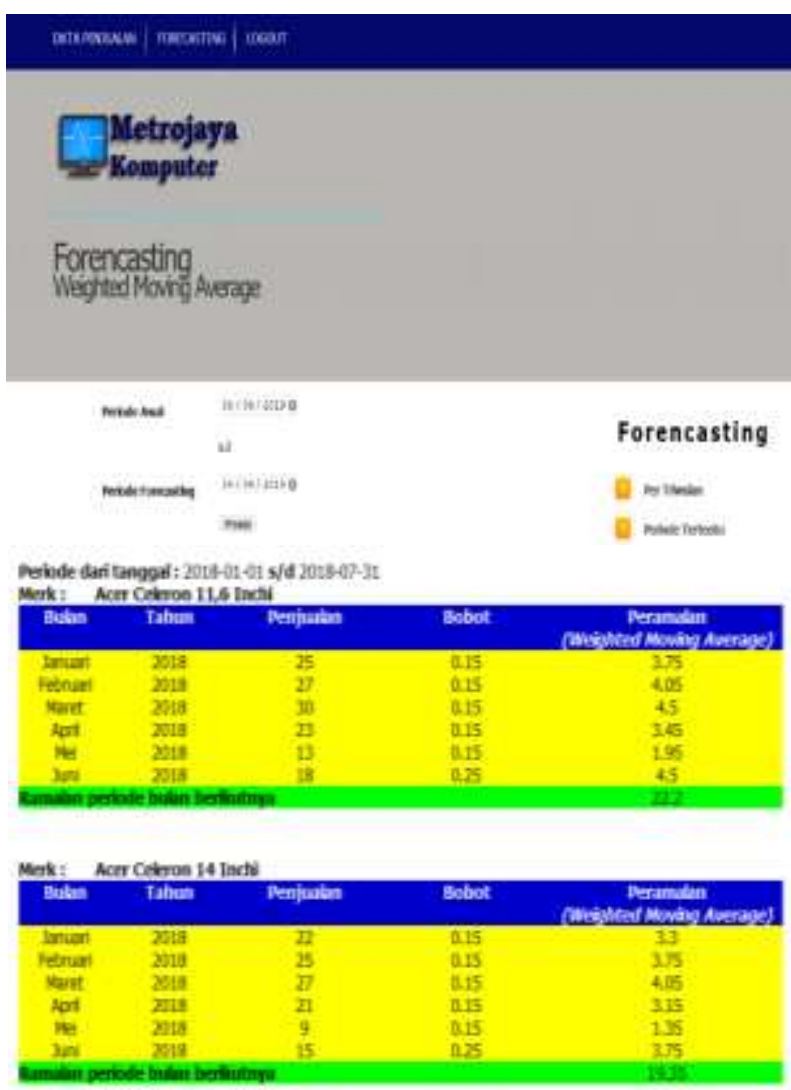

Gbr. 6 Forecasting menggunakan metode weighted moving average Berdasarkan periode tertentu.

\section{KESIMPULAN}

Forecasting menggunakan metode weighted moving average dapat memprediksikan berapa jumlah stok barang yang harus dibeli untuk periode selanjutnya. Perhitungan forecasting untuk periode kedepannya dilakukan berdasarkan perhitungan data pertriwulan sebelumnya dan bisa juga dilakukan berdasarnya pemilihan periode-periode yang diinginkan. Penelitian ini diharapkan membantu Metrojaya Komputer dalam memprediksikan pembelian stok barang untuk periode selanjutnya, sehingga bisa meminimumkan kesalahan jumlah pembelian stok barang. pada penelitian selanjutnya diharapakan peneliti bisa lebih dari satu metode yang digunakan dalam proses forecasting.

\section{UCAPAN TERIMA KASIH}

Peneliti ucapkan terimakasih kepada kepada pihak Metrojaya Komputer selaku tempat objek dari penelitian dan peneliti ucapkan terimakasih kepada Universitas Bina Darma selalu mensuport dalam melakukan penelitian.

\section{DAFTAR PUSTAKA}

[1] J. Heizer and B. Render, "Manajemen Operasi: Manajemen Keberlangsungan dan Rantai Pasokan," Jakarta: Salemba Empat, 2015.

[2] S. Alfarisi, "Sistem Prediksi Penjualan Gamis Toko QITAZ Menggunakan Metode Single Exponential Smoothing," JABE (Journal Appl. Bus. Econ., vol. 4, no. 1, pp. 80-95, 2017.

[3] S. S. Harahap, "Analisis kritis atas laporan keuangan, edisi 1," Jakarta Rajawali Pers, 2013.
[4] K. Nugraha, "PENERAPAN METODE PERAMALAN UNTUK MENYUSUN PERENCANAAN PRODUKSI PADA KONVEKSI ABYE GRAFFINDO.” Perpustakaan Fakultas Ekonomi dan Bisnis Unpas Bandung, 2018.

[5] D. Heryanto and I. Solikin, "PERAMALAN STOCK MOTOR PADA PT THAMRIN BROTHERS CABANG TUGU MULYO MENGGUNAKAN WEIGHTED MOVING AVERAGE (WMA)," Media Inform. dan Komput., vol. 6, no. 1, pp. 14-25, 2015.

[6] H. Tanuwijaya, "Penerapan Metode Winter's Exponential Smoothing Dan Single Moving Average Dalam Sistem Informasi Pengadaan Obat Rumah Sakit," in Prosiding Seminar Nasional Manajemen Teknologi XI, 2010.

[7] H. Azami, B. Bozorgtabar, and M. Shiroie, "Automatic signal segmentation using the fractal dimension and weighted moving average filter," J. Electr. Comput. Sci., vol. 11, no. 6, pp. 8-15, 2011.

[8] R. Y. Hayuningtyas, "Peramalan Persediaan Barang Menggunakan Metode Weighted moving average dan Metode Double Exponential Smoothing," J. Pilar Nusa Mandiri, vol. 13, no. 2, pp. 217-222, 2007.

[9] D. Rachmatin, "Penerapan Metode Exponentially Weigthed Moving Average (EWMA) dan Metode Semi Varians (SV) dalam Perhitungan Risiko Portofolio Saham PT Pindad Persero," Stat. J. Theor. Stat. Its Appl., vol. 15, no. 2, pp. 39-57, 2015.

[10] S. S. Sundari, S. Susanto, and W. Revianti, "Sistem Peramalan Persediaan Barang Dengan Weight Moving Average Di Toko The Kids 24," Proc. Konf. Nas. Sist. dan Inform., 2015.

[11] I. Solikin, "SISTEM INFORMASI PERAMALAN PEMBELIAN STOK BARANG MENGGUNAKAN METODE SINGLE MOVING AVERAGE (SMA)," J. Cendikia, vol. 12, no. 1, pp. 18-22, 2016.

[12] R. Rachman, "Penerapan Metode Moving Average Dan Exponential Smoothing Pada Peramalan Produksi Industri Garment," J. Inform., vol. 5, no. 2, pp. 211-220, 2018.

[13] T. Wedhasari, "Analisa Penggunaan Metode Peramalan Pada Perusahaan Retail Sistem Tradisional Market," Sinergi J. Tek. Mercu Buana, vol. 19, no. 2, pp. 165-170, 2015.

[14] M. P. K. Sugiyono, "Cara Mudah Menyusun: Skripsi." Tesis dan Disertasi, Bandung: Alfabeta, 2014

[15] J. Noor, "Metodologi penelitian: skripsi." tesis, disertasi, dan karya ilmiah, 2011.

[16] H. Herdiansyah, "Wawancara, observasi, dan focus groups: Sebagai instrumen penggalian data kualitatif," Jakarta PT. Raja Graf. Persada, 2013.

[17] H. Hasanah, "TEKNIK-TEKNIK OBSERVASI (Sebuah Alternatif Metode Pengumpulan Data Kualitatif Ilmu-ilmu Sosial)," AtTaqaddum, vol. 8, no. 1, pp. 21-46, 2017.

[18] I. Gunawan, "Metode penelitian kualitatif," Jakarta Bumi Aksara, 2013.

[19] R. M. Pressman, D. B. Sugarman, M. L. Nemon, J. Desjarlais, J. A. Owens, and A. Schettini-Evans, "Homework and family stress: With consideration of parents' self confidence, educational level, and cultural background," Am. J. Fam. Ther., vol. 43, no. 4, pp. 297-313, 2015.

[20] D. Suwardiyanto, M. N. Shodiq, D. H. Kusuma, and T. O. Sari, "Sistem Prediksi Kebutuhan Obat di Puskesmas Menggunakan Metode Least Square," J. Inform. J. Pengemb. IT, vol. 4, no. 1, 2019.

[21] A. Anisya and Y. Wandyra, "Rekayasa Perangkat Lunak Pengendalian Inventori Menggunakan Metode SMA (Single Moving Average) Berbasis AJAX (Asynchronous Javascript and XML)(Studi Kasus: PTP Nusantara VI (Persero) Unit Usaha Kayu Aro)," J. TeknoIf, vol. 4, no. $2,2016$.

[22] V. Gaspersz, "Production planning and inventory control," PT Gramedia Pustaka Umum, Jakarta, 2004.

[23] R. Agustina, "Stephen.(2015)," Anal. Fakt. yang Mempengaruhi Penerapan Konserv. Akunt. pada Perusah. Manufaktur yang Terdaftar di Bursa Efek Indones. SNA, vol. 18.

[24] C. Baktiar, A. Wibowo, and R. Adipranata, "Pembuatan Sistem Peramalan Penjualan Dengan Metode Weighted moving average dan Double Exponential Smoothing Pada UD Y," J. Infra, vol. 3, no. 1, p. pp-222, 2015.

[25] P. Sulistyanto, O. Wahyunggoro, and A. I. Cahyadi, "Pengolahan Isyarat Load cell Menggunakan Metode Simple Moving Average Tingkat Dua dan Weighted moving average Tingkat Dua untuk Pencarian Titik Referensi,” J. Inov. dan Kewirausahaan, 2015.

[26] A. Raharja, W. Angraeni, and R. A. Vinarti, "Penerapan Metode Exponential Smoothing Untuk Peramalan Penggunaan Waktu Telepon Di PT. Telkomsel Divre3 Surabaya," J. Sist. Inf., 2010. 